I should accordingly like to asi Mr. Galion whether he would indicate what, in his opinion, are the chief considerations to be taken into account in siving preference to the mean or the median as the better measure of the "average"? It is a point upon which there is considerable difference of opinion; the recognition of the median is rapidly extending, and some statisticians incline to think that there is a growing tendency to quote it in cases where the ordinury arithmetic mean is preferable.

March 16.

R. H. HOOKLR.

Rothesay Rainfall and the Sun.spot Cycle.

THE rainfall of Scotland has been thought to show, in its variations, an influence of the sun-spot cycle of eleven years (in the sense of most rain about maxima). Evidence of this was furnished not long ago by one of our ablest meteorologists, Dr. Buchan, in a paper to the Scottish Meteorological Society (Journal, 3 ser., Nos. xviii.-xix., p. II7).

For such an inquiry the record of Rothesay, in Bute, is singularly valuable, extending back as it does to the year 1800 in unbroken series.

The relation to the sun-spot cycle mav be traced, I think, not only in the total annual rainfall of Rothesay, but also, with more or less distinctness, in the amounts for certain sections of the year, and even individual months.



A, Rainfall July, Rothesay, $1800-1906$; smoxthed with sums of five; B, sun-spot curve.

Thus it is met with in the rainfall of summer, and especially that of July.

I have prepared a curve of the July rainfall (A), in which, by a familiar method, each year-point represents the rainfall of five contiguous Julys (i.e. $1800-4,1801-5$, and so on). Below is the sun-spot curve (B). The amount of correspondence between these two seems remarkable, and not easily explained by fortuitous coincidence.

Alex. B. MacDowall.

\section{The Relationship between Diamonds and Garnets.}

IN an able paper entitled "The Diamond Pipes and Fissures of South Africa," read before the Geological Society of South Africa rather more than a year ago, Mr. H. S. Harger refers more than once to the significance of the fact that diamonds have been found embedded in garnets. Perhaps the fact that the converse is also true, namely, that the garnet sometimes occurs embedded in the diamond, may not be without its share of interest. I have here at the present time a fragment of a Wesselton diamond, weighing a little more than a carat, containing a small, irregular garnet of about one-tenth of a carat. Originally the fragment seems to have formed a part of a shapeless diamond of perhaps two carats, which evidently enclosed either two or three small garnets, or garnets and diamonás.

Kimberley, South Alrica, February 20.

I. R. Sutton.
THE WEATHER REPORTS OF THE METEOROLOGICAL OFFICE.

THE commencement of the new year was marked by the introduction of a number of changes in the weather reports of the Meteorological Office.

Two notable events have contributed to bring about modifications in the daily report. Arrangements have been made for regular telegraphic reports from Iceland, and for occasional reports by wireless telegraphy from the ships of the Navy.

Thanks to the Danish Government and the Great Northern Telcgraph Company, the cable to Faeroe and Iceland, long desired by meteorologists and fishery associations, was laid in the summer of last year. There is a touch of sadness in the reflection that Adam Paulsen, director of the Danish Institute, who led the way so assiduously towards this meteorological Canaan, only got a distant view of the promised land. In August, I906, he issued a circular on behalf of the Danish Government, defining the terms of subscription for the service of meteorological telegrams from Iceland, but, as already reported in Nature, he died before the arrangements were completed.

Reports from Thorshavn in Faeroe and from Seydisfjord, on the east coast of Iccland, have been received in London, in a provisional way, since the end of October, but the meteoroiogical telegrams from Reykjavik, on the west coast, commenced on Friday, Iiebruary $\mathbf{1}_{5}$, as part of the full system which includes messages from Blönduos and Akureyri, where the land line touches the northern fjords, and Grimstadir, between the last-named place and Seydisfjord, where the cable lands. The meteorological arrangements are not complete even yet, for the reports do not conform to the established international model, either in uniformity of the hour of observation or the extent of the information transmitted; but those who have seen what the new information means for the weather map of north-western Europe, what light it throws upon the meteorological situation of the northern Atlantic, wiil appreciate the satisfaction that is felt with the result of the negotiations even in their present stage. Paulsen has indeed carved for himself a memorial aere perennius upon the winds and weather of the siormy northern island.

It is to the Lords of H.M. Treasury that we owe the realisation of this long-cherished project so far as this country is concerned. It need hardly be said that the cost of the n?w service is very considerable. Their lordships have undertaken to ask Parliament to increase the grant for meteorology from is,30ol., the figure at which it has stood since $1882-3$, by $200 l$., and the greater part of our share of the expenses for Iceland telegrams is thus provided for.

In order that the new information may be incorporated in the daily weather report the area of the charts has been extended to a more western longitude than hitherto, and the occasion has been utilised also to take in an area as far south as Gibraltar, and to meet a wish, often expressed, that a barometric chart of the 6 p.m. observations of the previous evening should be given. This appears as an inset chart on the same scale as "yesterday's" $8 \mathrm{a}, \mathrm{m}$. chart for the whole of Europe, side by side with the 8 a.m. chart for "to-day." But six o'clock observations NO. I95I, VOL. 75] 